\title{
REGULATION OF THE RIGHTS OF CHILDREN IN OUT-OF- HOME CARE BY TRUSTEE IN LATVIAN AND INTERNATIONAL POLITICS
}

Lubova Vasechko

University of Latvia

\begin{abstract}
This article provides an analysis of the way in which the Latvian regulatory framework in force determines the fulfilment of the needs of the child in out-of-home care by trustee and stability. This analysis indicates that in Latvian legislation the concept of "interests of the child" has not been clearly stated, in this regard, the Latvian legislation provides information of the rights of the child and the fulfilment of his physical needs. The concept of trustee and the existence of the concept is not mentioned. In contrast, international declarations and conventions on the topic of the protection of the rights of the child are much more humanitarian; in those documents, love and understanding from adults are acknowledged as the primary components in the harmonious development of the personality of the child.
\end{abstract}

Keywords: out-of-home care, trustee, rights of children, regulatory framework, interests of the child.

\section{Introduction}

In order to achieve full and harmonious development of the child, loving parents and family-oriented environment are required. In some cases, however, the biological family can hinder the development of the child. In such cases, it is the responsibility of Orphans ' Court to act and provide out-of-home care to the child.

Out-of-home care for the child - care that is provided by a guardian, foster family or child care institutions to orphans or children deprived of parental care (Protection of the Rights of the Child Law, 1998, Section 17).

Civil Law dictates that care means to provide (provide food, clothes, home, health care), to take care, to educate, and to raise (Civil Law, 1937). The institutions of out-of-home care provide orphans, children deprived of parental care, and children with special needs with day and night care, home, social rehabilitation, as well as support the reuniting of families or creation of new families (Requirements for Providers of Social Services, 2003).

In the UN Declaration of the Rights of the Child, passed in 1959, it has been indicated that a young child cannot be separated from his mother, except under specific conditions. These "specific conditions" are the reason for a large number of children in Latvia being in out-of-home care. There can be various reasons for it, but the similarity in all of them is being the basis for the ability of the government to intrude in the environment of families and separate the child from his parents.

In 2012, there were 8152 children in out-of-home care in Latvia. The largest number of children deprived of parental care (5 051) were under guardianship. 
Children that received care in foster families (1 155). Nevertheless, there is still a large number of children that do not have the possibility to have a foster family that could take care of them for at least a short period of time. In the end of 2012, in Latvian social care centres there were 544 children (children under the age of two, children under the age of four with physical and mental development disorders, and disabled children under the age of 18 with severe mental development disorders), whereas, there were 1402 children (from 2 to 18) in municipal social care centres (Children in Latvia, 2013).

The interests of the child in out-oh-home care are protected under the international regulatory framework and the regulatory framework of the Republic of Latvia. It is obvious, of course, that the phrase "the interests of the child in out-of home care" is contradictory because the child cannot be an interest in out-of-home care.

When discussing the protection of the rights of the child in out-of-home care, the actions and measures that provide the protection and care for the child that are required for his physical, psychological, and social well-being must be understood.

The UN Declaration provides guidelines indicating that country must use legislation and other instruments in order to provide a special protection for the child, as well as to create opportunities and conditions for healthy and normal physical, intellectual, moral, mental, and social development in conditions of freedom and respect. When adopting laws on this subject, the main priority should be the best possible way of ensuring the interests of the child (Declaration of the Rights of the Child, 1959).

Under the care of an institution, the child receives high quality physical care, the facility provides the best possible physical care, but it is not enough for a full psychological development of the child. Various research, carried out for 60 years, (Bowlby, 2003; Ambrose, 1961; Provence\&Lipton, 1962; Ainsworth, 1962; Pringle, 1965; Williamson\&Greenberg, 2010; Prihozhan, Tolstih, 2005, Ford, Kroll, 1995 and others) still verify the same results: a prolonged residence under institutional care during childhood leads to recurrent problems in social relationships, deviation in psychological development, difficulties of becoming a parent etc. J. Bowlby stresses that a terrible impact of the psyche of the child is left by the incapability to befriend an adult and create an emotional bond with him, as well as repeated rapture of existing bonds (Bowlby, 2006). The child will be capable of overcoming the loss of parents and successfully reorganize his inner world only if he has a possibility to have a person to whom he can trust. The person who substitutes the biological mother has two priorities: the person must always react and be approachable, and the person must step in every time the child faces difficulties. J. Bowlby asserts that it proves that the reaction of the trustee will determine if the child will grow up mentally healthy or not (Bowlby, 2003). The attitude of the adult, which expresses love and acceptance, 
creates a positive self-perception of the child and helps him to acknowledge his worthiness.

The goal of this article is to analyse the effectiveness of the legislation of the Republic of Latvia in determining the fulfilment of the needs of the child by the trustee and stability.

Method: content analysis.

\section{The Regulatory Framework of the Republic of Latvia}

The regulatory framework of Protection of the Rights of the Child of the Republic of Latvia is closely connected to the UN Declaration of the Rights of the Child, which provides guidelines that indicates that a country, using the legislation and other instruments, must provide a specific protection for the child, as well as to create opportunities and conditions for healthy and normal physical, intellectual, moral, mental, and social development in conditions of freedom and respect. When adopting laws on this subject, the main priority should be the best possible way to ensure the interests of the child (Declaration of the Rights of the Child, 1959). The Republic of Latvia ratified this document on 14 April, 1992 and it was adopted on 14 May, 1992.

The mutual rights and obligations between parents and the child in the Republic of Latvia are regulated in the Chapter 2 of Civil Law. It is stipulated that until the child reaches maturity, he is under the care and protection of his parents. Care and protection in this case - "the rights and obligations of parents to take care of their child and his property and represent the child in relations connected to privacy and property". Whereas, in Civil Law, "care" is explained as a way to provide for the child (food, home, clothes, health care), care of the child, his upbringing and education (to provide mental and physical development, acknowledging his individuality, abilities, and interests in order to rise the child capable of social work) (Civil Law, 1937).

It is curious that in the version of 1993 of the law "custody" was titled as "the power of parents", and only in 2002 after amendments of the law, the concept was changed to "custody" (Amendments to the Civil Law, 2002). These changes indicate the change in mindsets; the notion of parents having a power over their children as a property changed to rights to take care of their children and represent them as equal (Liepina, 2009).

In Civil law, the term "childcare" mostly indicates the interests of the child, however, it has not been stated anywhere in the law that in order to help the child become fully developed adult, the child needs at least one person that not only implements the care, but also is involved in the life of the child, is trustworthy, and has a significant role throughout the life of the child. Child care is fully implementable only if it has all necessary preconditions not only providing the physical development, but also develops the personality of the child and corresponds to the mental and emotional needs of the child. The main element of preconditions is the permanence of a reliable trustee. The author of 
this article believes that mental development and protection of the individuality of the child should be perceived as the primary elements, explaining the content of education and upbringing, not to be left out in brackets as additional information.

Section 181 of the law dictates that the child has rights to communication rights to sustain personal relations and direct contact with any of his parents (Civil Law, 1937). However, this section cannot be perceived as an obligation of the child because there often are cases in which parents are violent towards their children; the child cannot be made to meet his parents against his will even if the purpose would be the family reunification. This have been specified in Section 27 , which states that the child is taken from the family if his life, health or development is threatened by violence or suspicions of violence against the child; in these cases the child can be removed from family and the police can deny the information of the new location of the child to his parents, as well as all people the child has lived with for a long period of time (Protection of the Rights of the Child Law, 1998). Section 33 of Protection of the Rights of the Child Law regulates the communication between the child in out-of-home care and other people. Section 33 states that the "Orphans' Court which has taken the child in out-of-home care can refuse to disclose the information of the location of the child to his parents and other people, as well as make a decision to deny visitation" (Protection of the Rights of the Child Law, 1998, Section 33). This decision is made if visitation harm the health, development, and safety of the child or threatens the child or other children in facility.

Deprivation of the rights of protection or care and death of the parents of the child are the reasons for placing the child in out-of-home care or designation of a guardian if protection and care cannot be carried out by the other parent. Guardians replace the role of parents for the ward. One of the obligations of a guardian is management of the property of the ward. Section 256 of Civil Law dictates that "the goal for upbringing a minor is to provide care for his health and mentally and morally develop him in accordance with the condition of his property, his abilities and desires" (Civil Law, 1937). The author of this work believes that this is a negotiable question because the mental and moral development of the child should not be connected to the conditions of the property of the child. According to the author, there is and cannot be a connection between these two concepts. In present situation, the use of the term "desires" is controversial because in psychology it is defined as "the section or form of physiological and psychological needs when a person does not recognize the object of his needs and because of that is not aware of that. Desires mostly originates during childhood and deviations of the development of personality" (Dictionary of Psychology, 1999, 143). Dictionary of Pedagogical Terms adds notion to the definition that "desire" is effort to achieve, fulfil, acquire something. It is shown that "when necessity disappears, the desire can disappear or change into conscious wish or intention" (Dictionary of 
Pedagogical Terms, 2000, 175). Consequently, the desire is unconscious need, endeavour to achieve something. Analysing this term in context of Section 256 of Civil Law it can be assumed that the legislation states that it is an obligation of a guardian to take care of the health and development of the ward by satisfying the needs of the ward (minor) he does not recognize yet himself. For example, the need for care and love from the adult that the child might not recognize yet, but wishes to acquire and strives for.

Protection of the Rights of the Child Law indicates "the rights of the child, freedom and its protection that the child, as an intellectually and physically immature person, needs a specific protection and care" (Protection of the Rights of the Child Law, 1998, Section 1). It is closely connected to the UN Declaration of the Rights of the Child, Declaration on Social and Legal Principles relating to the Protection and Welfare of Children, and Convention of the Rights of the Child.

In Section 6 of Protection of the Rights of the Child Law, the concept of "the interests of the child" is mentioned. "Regardless of the actions carried out by public and municipal institutions, social organisations or other natural persons or legal entities, as well as courts and other law enforcement institutions, the interests and rights of the child must be the main priorities" (Protection of the Rights of the Child Law, 1998, Section 6). However, the specific interests of the child that should be prioritized are not clarified. Consequently, they should be clarified in the context of Civil Law.

Basic rights of the child can be found in Chapter 2 of Protection of the Rights of the Child Law, i.e., right to life and development, right to individuality, right to private life, right to freedom and immunity, right to adequate living conditions, right to education and creative work, social rights (professional training, health care, social assistance and social services, and other social guarantees provided by the government and municipalities), right to freedom of speech, right to acquire information, right to property, right to protection from exploitation (physical, mental, sexual, economical, work in hazardous conditions), right to leisure time, right to participate in the development of programmes connected to the rights of the child (Protection of the Rights of the Child Law, 1998).

The law contains social rights that are directly connected with out-of-home care, dictates the rights of the child to be protected and receive care in cases where the parents, subjects, do not carry out their obligations well enough.

Section 26 of Protection of the Rights of the Child Law establishes that each child has "his inalienable rights to grow up in a family" (Protection of the Rights of the Child Law, 1998, Section 26), and that is the natural environment for the development and growth of the child. This should not be adapted only to the biological family; if there is a reason the child cannot be in his biological family, the rights to live in a family must be ensured by placing the child into guardianship, foster family or alternative family, where the environment is made 
similar to the biological family in order to promote a healthy physical and mental development.

Section 6 of the law regulates out-of-home care that has the goal to "create a sense of protection, provide conditions for his development and well-being, support his efforts to become an independent person" (Protection of the Rights of the Child Law, 1998, Section 32). The author of this article wants to stress that this goal can be better achieved, if a safe bond with the adult is established, and the child experiences true care and love that are not clearly stated in the law. It is very important that these relations are stable and long-term. Completely opposite is the transfer of the child from one foster family to another; this transfer does not promote the sense of safety and attachment, and can cause severe consequences to an adequate development of the child.

Social Assistance and Social Services Law includes the term "life quality" which can be applied to the quality of out-of-home care as well. "Life quality" is "an indicator for welfare of a person, family, groups of people, public that includes physical and mental health, leisure time and the use of it, work, connection with the society, right to independently make and realize decisions, as well as material security" (Law on Social Services and Social Assistance, 2002, Section 1). Life quality could be perceived as a meter indicating the level of rights and protection of interests. In the aspect of the interests of child it is important to analyse the explanation of terms connected with physical and mental health, connection with the society, right to independently make and realize decisions, as well as material security. The goal of social care is to provide life quality to the people that, due to their age, (including children) cannot provide it for themselves (Law on Social Services and Social Assistance, 2002).

The author of this article will analyse this law, binding it with the conditions of providing the life quality in out-of-home care.

In Social Assistance and Social Services Law, the child (and all other persons), receiving social assistance and social services, is named "client" (Law on Social Services and Social Assistance, 2002, Section 1). Law offers an explanation for lasting social care institution, i. e., "social institution (...) provides a home, full care and social rehabilitation "to orphans and children deprived of parental care" (Law on Social Services and Social Assistance, 2002, Section 1). However, in Civil Law, "care" has been defined as a way to provide for the child (provision of food, clothes, home, and health care), child care, education and upbringing (ensure mental and physical development, acknowledging his individuality, abilities, and interests in order to rise the child capable of social work) (Civil Law, 1937, Section 177).

The law provides the following basic principles for the children deprived of parental care and care of these children in out-of-home care institutions: primarily - care in family environment; actions, carried out during the time the child is in out-of-home care that contribute to the return of the child to his 
biological family (if possible); conversion of the environment of institutions into family-oriented environment, and helping to master the skills necessary in life (Law on Social Services and Social Assistance, 2002, Section 4).

Unfortunately, the present environment in the out-of-home care institutions of the Republic of Latvia is very distant from family-oriented environment because it lacks the most important factor - emotional and individual relations, and the trustee, permanent caretaker. In light of life quality, while the child is in out-ofhome care institution, he does not have a fully provided bond with the society; it is the reason why there have been so many discussions on the topic of integration of adult persons raised in institutionalized care into the society. The lack of family-oriented environment can result in unbalanced socially emotional development.

Chapter IV of Law on Social Services and Social Assistance reveals the rights of persons, living in long-term social care institutions, e.g.,"to have an individual approach, while receiving social services from the staff of the institution" (Law on Social Services and Social Assistance, 2002, Section 29, Clause 2). Of course, there are children who state that they receive an individual approach, living in out-of-home care institutions, but still this approach is different from one they received before living in the institutions. This question requires further discussions because individual approach in out-of-home care institutions is not fully provided, and the institutional care itself does not provide such care, and the implementation of such an approach would be relatively difficult.

Law on Social Services and Social Assistance determines the professional tasks of the social caretaker. The social caretaker is a worker who carries out social care in out-of-home care public and municipal institutions. His obligations consist of planning the social services to satisfy the basic needs, determining the need for combined or separate social services according to the wishes and needs of a client, as well as organizing the provision of social services (Law on Social Services and Social Assistance, 2002). It is curious that only basic needs are indicated here. It is known that, according to A. Maslow's hierarchy of needs, the basic needs include physical needs: air, sleep, sustenance, warmth, health, living space, sexuality (Maslow, 1954). If a person who works with the child every day satisfies only his basic needs, the child will not have the individual approach, and in such cases the legislation should determine a person and his range of duties that will satisfy the highest needs for the child (a need for family, friendship, group support, love, intimacy, communication); if the legislation does not determine such a worker, full provision of all interests of the child is impossible.

\section{International Regulation}

Declaration of the Rights of the Child has been declared in 1959 with the decision of the General Assembly of the United Nations Organisation. It contains ten principles that the member states undertake to fallow by adopting 
laws and implementing various measures. The second principle of the Declaration: "using legislation and various instruments, the child must be provided with specific protection, as well as opportunities and conditions for healthy and normal physical, intellectual, moral, mental, and social development in conditions of freedom and respect. When adopting laws on this subject, the main priority should be the best possible way to ensure the interests of the child" (Declaration of he Rights of the Child, 1959). Here the concept "the interests of the child" can be observed. The Declaration does not provide an explanation for this definition, nevertheless, the content of the concept is revealed in Principle 6, i. e., "in order to insure a full and harmonious development of the personality of the child, love and understanding are required." If it is possible, the child should grow up in the care and custody of his parents, and the child must live in conditions he feels loved and morally and materially supported; a young child cannot be separated from his mother, except under specific conditions" (Declaration of the Rights of the Child, 1959, Principle 16).

Here it is possible to conclude that love and understanding from the adults are perceived as important components for harmonious development of the personality of the child. It is also stated that it is possible to separate the child from his parents under specific conditions, but out-of-home care institutions are not mentioned as alternative care in this Declaration. Possibly, because "the placement" of the child in such institutions would contradict the interests of the child.

Another document of UN, regulating the rights of the child in out-of-home care, is Declaration on Social and Legal Principles relating to the Protection and Welfare of Children, with Special Reference to Foster Placement and Adoption Nationally and Internationally; this Declaration is adopted in the resolution of UN General Assembly of 1986. It contains three parts: General Family and Child Welfare, Adoption, Foster Placement (Declaration on Social and Legal Principles relating to the Protection and Welfare of Children, with Special Reference to Foster Placement and Adoption Nationally and Internationally, 1986).

The interests of the child and necessity to consider them are mentioned in the arguments and considerations of the preamble of the Declaration: "in all the procedures connected to foster placement and adoption the main priority is to consider the interests of the child" (Declaration on Social and Legal Principles relating to the Protection and Welfare of Children, with Special Reference to Foster Placement and Adoption Nationally and Internationally, 1986).

The fundamental principles, included in this document, indicates that the wellbeing of the child depends on the well-being of the parents, and it is important that the child is in care of his biological parents. Clause 5 describes the actions that should be taken if the care of biological parents is impossible (or it undermines the child to any kind of violence) and determines that "in all questions connected to foster placement the most important interests of the child 
must be taken into consideration, especially, his or her need for love and rights to safe and permanent care" (Declaration on Social and Legal Principles relating to the Protection and Welfare of Children, with Special Reference to Foster Placement and Adoption Nationally and Internationally, 1986, Section 5). In contrast to Law on Social Services and Social Assistance of the Republic of Latvia, where the stress is put on the basic needs of the child, the Declaration accents the need of the child for sense of safety and love. It is possible that such a situation has arisen because there have not been developed criteria for "love".

\section{Conclusions}

Performing the analysis on the regulation of out-of-home care on the level of national politics, the author has discovered that the standards in the legislation of the Republic of Latvia correspond to the UN principles, almost completely copying the suggestions of the Committee mentioned above. The existing problem affects the implementation of the practical standards, stated in the legislation. The author believes that, in order to improve the situation, it is necessary to strengthen the control over the implementation of standards and carefully oversee the actions of institutions involved, revealing the cases the rights of the child in out-of-home care are not ensured.

The analysis of the legislation revealed a number of deficiencies, e. g., the lack of definition for the interests of the child, as well as lack of sections, indicating the needs of the child by trustee, love, individual approach and understanding; without which the interests of the child cannot be ensured, and adequate social, emotional and physical development cannot be promoted.

The principles of the international declarations and conventions, which the legislation of the Republic of Latvia has undertaken to follow and implement, are more humane in the field of the protection of the interests of the child; the care and understanding from adults have been considered to be the most important factors in the harmonious development of the personality of the child. Considering the written above, the author of this article concludes that amendments in the legislation of the Republic of Latvia, regulating the rights of the child in his biological family and out-of-home care, and society as such, should be carried out. For example, the definition of the term "childcare" should be extended with the information of providing close relations with a person of attachment; specify regulatory framework which dictates the rights of the child to be heard and speak freely, as well as specify regulatory framework for other issues, the author indicated, while analysing the regulation of out-of-home care, e.g., in light with the Protection of the Rights of the Child Law, specify the definition of the concepts - "the interests of the child" and "childcare", as well as introduce amendments in Section 46, Clause 1 of Law on Social Services and Social Assistance, determining that caretaker must provide not only the basic needs, but also the highest level of needs to his clients (children). 


\section{References}

1. Bērni Latvijā, 2013 (Children in Latvia, 2013). Rīga: Latvijas Republikas Centrālā statistikas pārvalde, 2013. [reference 24.01.14.]. Retrieved from http://www.csb.gov.lv/dati/e-publikacijas/berni-latvija-2013-38420.html

2. Bèrnu tiesìbu aizsardzības likums (Protection of the Rights of the Child Law). Rìga: Latvijas Saeima, 1998. [reference 13.01.14.]. Retrieved from http://likumi.lv/doc.php?id=49096

3. Bērnu tiesību deklarācija (Declaration of he Rights of the Child). Apvienoto Nāciju organizācija, 1959. [reference 20.11.11.]. Retrieved from http://www.humanrights.lv/doc/vispaar/berndekl.htm

4. Civillikums (Civil Law). Rīga: Latvijas Saeima, 1937. [reference 21.11.11.]. Retrieved from http://www.likumi.lv/doc.php?id=90223

5. Deklarācija par bērna aizsardzības un labkläjības sociālajiem un tiesiskajiem principiem, it īpaši attiecībā uz bērnu nodošanu audzināšanā vai nacionālo vai starptautisko adopciju (Declaration on Social and Legal Principles relating to the Protection and Welfare of Children, with Special Reference to Foster Placement and Adoption Nationally and Internationally). ANO: 1986. [reference 20.02.12.]. Retrieved from http://www.tiesibsargs.lv/lat/tiesibu_akti/ano_dokumenti/?doc=98

6. Grozìjumi Civillikumā (Amendments to the Civìl law). Rīga: Latvijas Saeima, 2002. [reference 12.03.12.]. Retrieved from http://www.likumi.lv/doc.php?id=69563\&from=off

7. Liepiņa, L. (Liepina) (2009) Bērnu intereses un ārpusǵimenes aprūpe Latvijā: mağistra darbs (The Interests of the Child and out-of-home care in Latvia: Master's Thesis). LU Pedagog̣ijas, psiholog̣ijas un mākslas fakultāte. Rīga: Latvijas Universitāte, 77. 1pp.

8. Maslow, A. H. (2000) Motivation and Personality. New York: Harpaer \& Row, 1954

9. Pedagogijas terminu skaidrojošā vārdnīca (Dictionary of Pedagogical Terms): autoru kolektīvs V. Skujiņas vadībā. Rīga: Zvaigzne ABC, 248. lpp.

10. Prasības sociālo pakalpojumu sniedzējiem (Requirements for Providers of Social Services). MK noteikumi Nr. 291, Rīga: Ministru Kabinets, 2003. [reference 21.11.11.]. Retrieved from http://www.likumi.lv/doc.php?id=124793

11. Psihologijas vārdnīca (Dictionary of Psychology): G. Breslava redakcijā. Rīga: Mācību grāmatas, 1999. 157. lpp.

12. Sociālo pakalpojumu un sociālās palīdzības likums (Law on Social Services and Social Assistance). Rīga: Latvijas Saeima, 2002. [reference 21.11.11.]. Retrieved from http://www.likumi.lv/doc.php?id=68488

13. Боулби, Дж. (Bowlby) (2006) Создание и разрушение эмоииональных связей (Creation and Destruction of Emotional Bonds). 2-е издание. Москва: Академический проект, 238 c.

14. Боулби, Дж. (Bowlby) (2003) Привязанность (The Attachment). Москва: Гардарики, $447 \mathrm{c}$.

$\begin{array}{ll}\text { Mag. sc.administr. } & \text { University of Latvia } \\ \text { Lubova Vasechko } & \text { Faculty of Education, Psychology and Art } \\ & \text { Jūrmalas avenue 74/76, Rīga, LV - 1083 } \\ & \text { e-mail: lv06028@lanet.lv } \\ & \text { tel. +371 27063307 }\end{array}$

